\title{
Land Use Change and Nutrients Simulation for the Siah Darvishan Basin of the Anzali Wetland Region, Iran
}

\author{
M. Ghafouri $\cdot$ N. Ghaderi $\cdot$ M. Tabatabaei $\cdot$ \\ V. Versace $\cdot$ D. Ierodiaconou $\cdot$ D. A. Barry $\cdot$ \\ F. Stagnitti
}

Received: 17 June 2008/Accepted: 15 October 2009/Published online: 6 November 2009

(C) Springer Science+Business Media, LLC 2009

\begin{abstract}
The Anzali Ramsar Convention wetland is located in an ecologically and economically important region in Iran. The wetland is largely surrounded by agriculture, natural forests and rangelands (approximately $36 \%$ and $63 \%$, respectively). Urban areas consist of less than $1 \%$ of the total area. Urban land use produces the highest rates of nutrient transfer into the lake as TN, TP and BOD5 equal to $24,2.4$ and $79 \mathrm{Kg} / \mathrm{ha} /$ year, respectively, whilst, natural land use produces the lowest rate as 10, 1.3 and $27 \mathrm{~kg} / \mathrm{ha} / \mathrm{year}$. These results will inform the future sustainable management of this important wetland in this ever increasingly water stressed region in Iran.
\end{abstract}

Keywords Ramsar wetlands · Nutrients · Nitrogen · Phosphorus · Pollution · Transfer model $\cdot$ Landuse

M. Ghafouri · M. Tabatabaei

Soil Conservation and Watershed Management Research Institute (SCWMRI), P.O. Box 1344-1136, Tehran, Islamic Republic of Iran

N. Ghaderi

Agriculture and Natural Resources Research Center, Kurdestan Province, Islamic Republic of Iran

V. Versace $\cdot$ D. Ierodiaconou $\cdot$ F. Stagnitti $(\bowtie)$

School of Life and Environmental Science, Deakin University, Warrnambool, VIC 3280, Australia

e-mail: f.stagnitti@ballarat.edu.au

D. A. Barry

Laboratoire de technologie écologique (ECOL),

Faculté de l'environnement naturel, architectural et construit (ENAC), Ecole Polytechnique Fédérale de Lausanne (EPFL), 1015 Lausanne, Switzerland
In 1995 about 2.3 billion people (about $41 \%$ of the world's population at the time) lived in river basins considered to be water stressed and this value has been predicted to increase to 3.5 billion by 2025 (approximately $48 \%$ of the projected population) (World Resources Institute 2000; Hamilton et al. 2007). Inappropriate land use may result in serious environmental degradation of water quality (Versace et al. 2008). Effective environmental planning requires accurate models to predict nutrient loads that are discharged from spatially variable land use units within river basins as runoff (Ierodiaconou et al. 2005). Hence accurate and timely prediction of its water resources is essential to maintain water supply, quality and security.

Iran, like many others is a country with scarce water resources and has experienced severe drought conditions in 1991-2001. The Anzali wetland is located in an ecologically and economically important region in Iran. The wetland is largely surrounded by agriculture (approximately 36\%) and natural forests and rangelands (approximately $63 \%$ ). Urban areas consist of less than $1 \%$ of the total area. In 2005, the Department of the Environment of the Province of Guilan, Iran was internationally recognized by winning the Ramsar Wetland Conservation Award for the "major and pivotal role in the establishment of an effective conservation and wise use scheme for the 15,000 ha Anzali Wetland Ramsar Site, designated in 1975" (http://www.ramsar.org/award/key_awards2005_ report_e.htm). "The Convention on Wetlands, signed in Ramsar, Iran, in 1971, is an intergovernmental treaty which provides the framework for national action and international cooperation for the conservation and wise use of wetlands and their resources"(http://www.ramsar.org). The wetland acts as a buffer to the Caspian Sea filtering nutrients and sediments. Herein is the first reported quantitative study of nutrient inputs into the Anzali wetlands 
from the surrounding basin. This paper also reports on modelling efforts to predict the pollution loads generated from land surrounding this important wetland.

\section{Materials and Methods}

The study region is one of sub-catchments of Anzali wetland located between the coordinates of $49^{\circ} 03^{\prime}$ to $49^{\circ} 27^{\prime}$ eastern latitude and $37^{\circ} 20^{\prime}$ to $37^{\circ} 23^{\prime}$ northern longitudes in Guilan Province (see Fig. 1). It is known as Siah Darvishan catchment or locally called Pish Roubar. The catchment area is $494.2 \mathrm{~km}^{2}$. The Laxar hydrometric station is located at the catchment's outlet and discharges into the wetland. The catchment consists of four sub-catchments or hydrologic units named Ghaleh Rood Khan, Gasht Rood Khan, and units 45 and 46 (Ghaderi 2000). The upland and southern parts of the catchment are bordered by a common mountain range between Guilan and Zanjan provinces. In addition to the Laxar gauging station, there are another three hydrometric stations, as shown in Fig. 1, measuring discharge from the sub-catchments.

The climate is very humid. The average annual temperature is $15.7^{\circ} \mathrm{C}$ and average rainfall is approximately $1,300 \mathrm{~mm}$. The catchment comprises of different land uses: approximately $36 \%$ of the catchment is agricultural and $63 \%$ is forest and rangeland. Less than $1 \%$ of the catchment is used for urban or residential purposes. A comprehensive land use analysis and a map was produced by Ghaderi (2000).

Sampling points for each land use were selected for the four sub-catchment outlets and samples were taken in three seasons each replicated four times. The water quality parameters measured were TN, TP, TSS and BOD. The total nutrient load of the catchment was calculated using runoff coefficients estimated from water balance and compared to the observed data for each hydrologic unit.

The AQUALM computer program was used to model nutrient loads in the catchment. The AQUALM model is a comprehensive water quality management tool for predciting surface and subsurface runoff and pollutant export, transport and routing (WP Software 1995, http://www. xpsoftware.com/products/pdfs/Aqmtdes.pdf). AQUALM is a lumped model that uses average parameters of catchment characteristics and rainfall-runoff data. The model consists of seven modules as follows:

- the foundation module as rainfall-runoff model used in calculation of pollutants load

- rainfall-lake

- river pollution transfer

- gross pollutant trap

- lake or pool water deterioration

- point and non-point source pollution transfer modules

The model applications include; impact of urbanization on river quality, impact of sewage point discharge on lake
Fig. 1 Location map illustrating the Siah Darvishan river basin

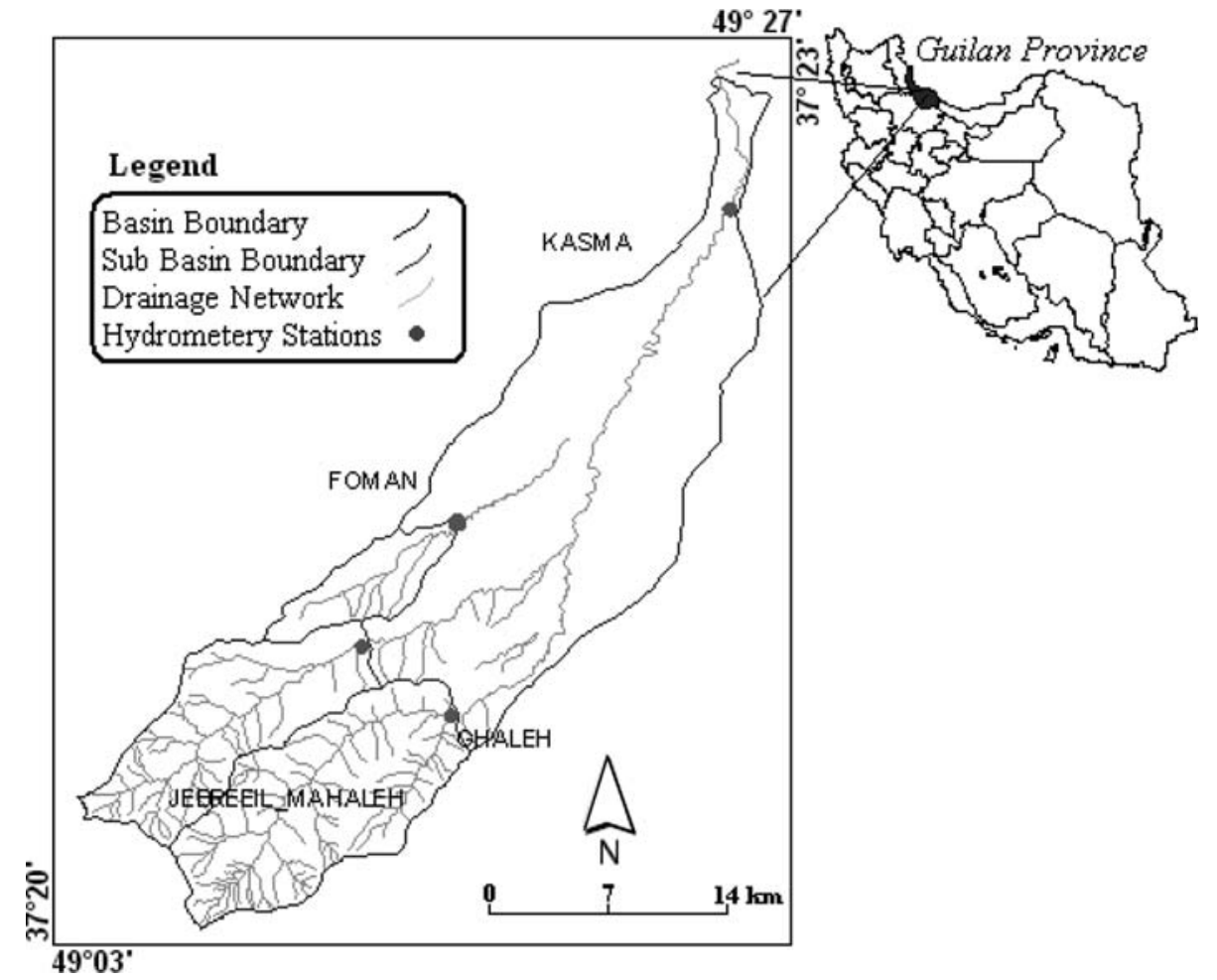


health, impact of urban storm water on coastal waters, sizing of water quality control structures, land use impact on pollution transfer and simulation of daily and monthly pollution loads (Phillips and Ghafouri 1997).

The model was previously tested on the Zarivar lake region in west of Iran (Ghaderi 2000). In the current research the model was calibatrated using the 1989-1990 water year as an "average" year with rainfall of approximately $1,300 \mathrm{~mm}$ and the two water years of 1997-1998 and 1994-1995 were selected as wet and dry years for validation of the results respectively.

The main data required for the model are as follows:

- land use type,

- monthly evaporation, pan evaporation and pan coefficient

- average monthly temperature

- permeability of soils

- daily rainfall for each land use,

- daily irrigation magnitude for each land use

- determination of surface runoff

- estimation of hydrologic equation coefficients for each land use

- pollution transfer equation coefficients for each pollutant and land use

- land use area and runoff depth (WP Software 1995).

Daily rainfall was been determined using an isoheytal map. Daily rainfall depth was supplied to the model as the average of daily rainfall over the catchment. The effective moisture storage coefficients in the water balance of the catchment were calculated and supplied to the model as a batch of 13 parameters. The coefficients of pollution were based on the average runoff for each land use and the pollution load of the unit area. The Pan evaporation was supplied to the model in $\mathrm{mm} / \mathrm{month}$, along with monthly depth of irrigation for agricultural, orchards, park and green areas in $\mathrm{mm}$. Grain size analysis for each surface layer of each land use soil type was specified in the model as percentages and in $\mathrm{mm}$ respectively.

Direct runoff calculated in the model is as follows (WP software 1995):

$\mathrm{RO}=a \mathrm{RF}+b$

where RO is the daily direct runoff (mm) and $a$ and $b$ are calibration coefficients. RF is the daily rainfall (mm). Evapotranspiration is calculated as follows:

$\mathrm{ET}=d \mathrm{EV} \frac{\mathrm{US}_{\text {store }}}{\mathrm{US}_{\max }}$

where ET is the daily evapotranspiration $(\mathrm{mm})$ and " $d$ " is a calibration coefficient. EV is the daily pan evaporation $(\mathrm{mm}), \mathrm{US}_{\text {store }}$ is the current moisture in soil surface layer $(\mathrm{mm}), \mathrm{US}_{\max }$ is the maximum moisture in soil surface layer which is equal to the field capacity FC. The interflow is calculated using:

$\mathrm{TF}=\mathrm{Kt} \frac{\left(\mathrm{DR}_{\text {store }}\right)^{2}}{\mathrm{DR}_{\max }}+e \frac{\left(\mathrm{US}_{\text {store }}\right)^{2}}{\mathrm{US}_{\max }}$

$\mathrm{TF}$ is the through-flow below the soil surface (mm), Kt and $e$ are calibration coefficients, $\mathrm{DR}_{\text {store }}$ is the soil drainage storage and $\mathrm{DR}_{\max }$ is the maximum soil drainage storage (mm). Equation (4) is used for calculating transmission loss to deep ground storage that is transferred via drainage storage or soil moisture storage to deep ground water area.

$\mathrm{LDU}=f \frac{\left(\mathrm{US}_{\text {store }}\right)^{2}}{\mathrm{US}_{\max }}$

LDU is the water transfer to deep storage from moisture stored at surface layer of soil $(\mathrm{mm})$ and $\mathrm{f}$ is a calibration coefficient. Equation (5) is used for water transfer from drainage soil storage to deep storage.

$\mathrm{LDD}=g \mathrm{DR}_{\text {store }}$

LDD is the water transfer to deep storage (mm), $g$ is the calibration coefficient, $\mathrm{DR}_{\text {store }}$ is the soil drainage storage $(\mathrm{mm})$. LDD can be alternatively calculated by:

$L D D=g \frac{D_{\text {store }}^{2}}{R_{\max }}$

The total water entering deep storage is calculated by Eq. (7) and the surface runoff will be calculated by the difference between rainfall and TLD.

$\mathrm{TLD}=\mathrm{LDD}+\mathrm{LDU}$

The coefficients of $a, b, \mathrm{Kt}, e, f$ and $g$ are essentially functions of the soil. They are calibrated or estimated characteristics. Equation (8) is used for calculating pollution load transfer,

$\mathrm{PE}=a R^{b}$

where PE is the pollutant load ( $\mathrm{kg} / \mathrm{ha}), a$ is a calibration coefficient related to the average concentration of pollutants for each land use, $b$ is a calibration coefficient related to magnitude of runoff and soil slope and $R$ is the surface runoff.

\section{Results and Discussion}

The hydrologic and pollution coefficients for the model are shown in Tables 1 and 2. After calibration of the rainfallrunoff module for average hydrologic conditions of the catchment, the model was verified for two wet and dry years. The pollution load in one unit area was computed and compared with the observed value. When required the pollutant load equation coefficients was adjusted. The 
Table 1 Interception, surface soil storage and soil drainage storage used in the calibration of AQUALM model

\begin{tabular}{|c|c|c|c|c|c|c|}
\hline \multirow[t]{2}{*}{ Parameter } & \multicolumn{3}{|c|}{ Initial values } & \multicolumn{3}{|c|}{ Maximum value } \\
\hline & Natural & Agriculture & Urban & Natural & Agriculture & Urban \\
\hline Interception & 0 & 0 & 0 & 3 & 2 & 3 \\
\hline Soil drainage & 0 & 0 & 0 & 40 & 60 & 10 \\
\hline Surface soil storage & 35 & 40 & 50 & 60 & 85 & 10 \\
\hline
\end{tabular}

hydrologic module was applied to daily runoff from the catchment. The module was applied once without any attempt to calibrate the hydraulic equation coefficients. The mean absolute error (MAE) of monthly flow was initially

Table 2 Hydrological process coefficients used in the AQUALM model

\begin{tabular}{llccc}
\hline Coefficient & Parameter used & \multicolumn{2}{l}{ Land use values } \\
\cline { 3 - 5 } & in model & Natural & Agricultural & Urban \\
\hline$a$ & RO & 0.15 & 0.15 & 0.7 \\
$b$ & RO & -0.04 & -0.05 & -0.2 \\
$d$ & ET & 0.7 & 0.7 & 0.7 \\
$\mathrm{Kt}$ & TF & 0.2 & 0.15 & 0.25 \\
$e$ & TF & 0.02 & 0.002 & 0.007 \\
$f$ & LDU & 0.1 & 0.015 & 0 \\
$g$ & LDU & 0.03 & 0.005 & 0 \\
\hline
\end{tabular}

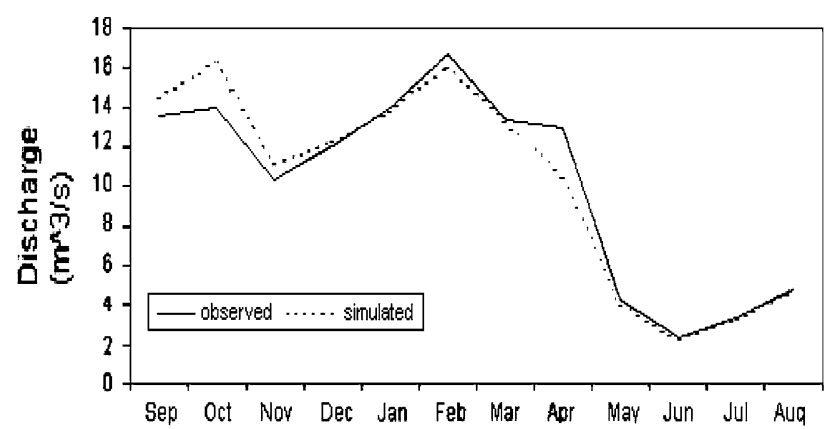

Fig. 2 Simulated and observed monthly hydrograph for the Basin following calibration calculated and equalled 2.8\%. After calibration the MAE was reduced to $0.3 \%$ (see Fig. 2).

The calculated pollution loads (TN, TSS, BOD5 and $\mathrm{TP})$, resulting from the calibrated model for each land use are presented in Table 3. The corresponding calibrated coefficients of $a$ and $b$ in the pollution transfer equations are presented in Table 4 .

The catchment average annual load of pollutants is indicated in Table 5. Comparisons of modeled parameter values against observed values for both dry and wet years are shown in Tables 6 and 7 . These tables show that there

Table 4 Calibrated coefficients of pollution transfer equations for each land use

\begin{tabular}{|c|c|c|c|c|c|c|}
\hline \multirow{3}{*}{$\begin{array}{l}\text { Pollutant } \\
\text { type }\end{array}$} & \multicolumn{6}{|c|}{ Land use pollution transfer equation coefficient } \\
\hline & \multicolumn{2}{|l|}{ Natural } & \multicolumn{2}{|c|}{ Agricultural } & \multicolumn{2}{|l|}{ Urban } \\
\hline & $a$ & $b$ & $a$ & $b$ & $a$ & $b$ \\
\hline $\mathrm{TN}$ & 0.03750 & 0.15 & 0.0396 & 0.30 & 0.0816 & 0.15 \\
\hline $\mathrm{TP}$ & 0.0037 & 0.10 & 0.0078 & 0.41 & 0.0076 & 2.60 \\
\hline TSS & 2.06200 & 1.00 & 0.7500 & 1.00 & 4.3000 & 1.00 \\
\hline BOD & 0.07000 & 0.900 & 0.0740 & 0.900 & 0.2150 & 0.55 \\
\hline
\end{tabular}

Table 5 Predicted annual load of pollutants (tonne/year)

\begin{tabular}{|c|c|c|c|c|}
\hline Land use & $\mathrm{TN}$ & $\mathrm{TP}$ & TSS & BOD \\
\hline Natural & 373 & 43.50 & 47,890 & 1,150 \\
\hline Agricultural & 263 & 68.50 & 9,720 & 838 \\
\hline Urban & 85 & 0.80 & 14,400 & 30 \\
\hline Total & 7,231 & 112.80 & 59,050 & 2,008 \\
\hline
\end{tabular}

Table 3 Calculated pollution loads ( $\mathrm{kg} / \mathrm{ha}$ ) using the calibrated model

\begin{tabular}{|c|c|c|c|c|c|c|c|c|}
\hline \multirow[t]{3}{*}{ Land Use } & \multicolumn{8}{|c|}{ Pollution load (kg/ha) } \\
\hline & \multicolumn{2}{|l|}{$\mathrm{TP}$} & \multicolumn{2}{|l|}{ TSS } & \multicolumn{2}{|l|}{ BOD } & \multicolumn{2}{|l|}{$\mathrm{TN}$} \\
\hline & Sim & Obs & Sim & Obs & Sim & Obs & $\operatorname{Sim}^{\mathrm{a}}$ & Obs \\
\hline Natural & 1.40 & 1.37 & $1,500.0$ & $1,540.0$ & 37.00 & 37.00 & 13.00 & 12.50 \\
\hline Agriculture & 3.50 & 3.00 & 540.0 & 540.0 & 46.00 & 46.00 & 15.00 & 14.60 \\
\hline Urban & 2.60 & 2.55 & $4,500.0$ & $4,500.0$ & 95.00 & 95.00 & 27.00 & 26.50 \\
\hline
\end{tabular}

a Sim Simulated, Obs Observed 
Table 6 Evaluation of simulated results of pollution compared with observed data for dry years

\begin{tabular}{|c|c|c|c|c|c|c|c|c|}
\hline \multirow[t]{3}{*}{ Land use } & \multicolumn{8}{|c|}{ Pollution (kg/ha/year) } \\
\hline & \multicolumn{2}{|l|}{ TSS } & \multicolumn{2}{|l|}{$\mathrm{TN}$} & \multicolumn{2}{|l|}{$\mathrm{TP}$} & \multicolumn{2}{|c|}{ BOD5 } \\
\hline & Sim & Obs & Sim & Obs & Sim & Obs & Sim & Obs \\
\hline Natural & 1,400 & 1,450 & 10 & 8.5 & 1.3 & 1.27 & 27 & 26.2 \\
\hline Agriculture & 430 & 455 & 12 & 11 & 2.4 & 2.1 & 36 & 32.5 \\
\hline Urban & 3,900 & 5,000 & 24 & 23 & 2.4 & 2.6 & 79 & 82 \\
\hline
\end{tabular}

Table 7 Evaluation of simulated results of pollution compared with observed data for wet years

\begin{tabular}{|c|c|c|c|c|c|c|c|c|}
\hline \multirow[t]{3}{*}{ Land use } & \multicolumn{8}{|c|}{ Pollution (kg/ha/year) } \\
\hline & \multicolumn{2}{|l|}{ TSS } & \multicolumn{2}{|l|}{$\mathrm{TP}$} & \multicolumn{2}{|l|}{$\mathrm{TN}$} & \multicolumn{2}{|c|}{ BOD5 } \\
\hline & Sim & Obs & Sim & Obs & Sim & Obs & Sim & Obs \\
\hline Natural & 2,000 & 2,100 & 14 & 13.6 & 1.5 & 2 & 48 & 42 \\
\hline Agriculture & 750 & 700 & 16 & 17 & 3.5 & 3.2 & 62 & 50 \\
\hline Urban & 5,800 & 7,750 & 29 & 35 & 3.2 & 4 & 113.5 & 127 \\
\hline
\end{tabular}

was excellent agreement between modeled results and observed values.

The hydrological module of the AQUALM software simulated runoff reasonably well with an error of $2.8 \%$. Verification of this module on both wet and dry years showed maximum errors of $7.5 \%$ and $4.5 \%$, respectively. The average error of the model for the predicted pollution load was $\pm 2.5 \%$ for the calibrated period, however, in worst case the error reached $8.5 \%$, which for basin management purposes is sufficient. The urban land use has the highest production of BOD and TSS on a unit area basis. However, this is only a small component of the overall total land use. The agricultural land produces the maximum TP and TN contributions to the wetland. The natural land use, forests and rangelands, has the least pollution-transfer rates, which confirms the need to preserve its vital role in environmental protection of this important wetland region of Iran.

The calibrated AQULM-XP model is used as a tool to quantify the impacts of land use change and to assist in the formulation of management strategies to address inverse impacts. A range of management strategies can be generated and possible impacts can be quantified to preserve the wetland. Management strategies may include; restrictions on some land use changes, location constraints, identification of buffer and conservation zones and provision of pollution control structures such as gross pollutants trap and treatment ponds. Land use scenarios can be assessed in terms of their pollutant exports relative to sustaibnable loads, social, economic, and administrative objectives, as the basis for identifying the preferred Integrated Management Strategy for the Anzali Ramsar Wetland and its surrounding catchments.

\section{References}

Ghaderi N (2000) Effect of land use on run-off quality of Zarivar's lake watershed of Marivan city MSc thesis, Tehran 153p

Hamilton A, Stagnitti F, Xiong X, Kreidl S, Benke K, Maher P (2007) Wastewater irrigation: The state of play. Vadose Zone J 6:823840

Ierodiaconou D, Laurenson L, LeBlanc M, Stagnitti F, Duff G, Salzman S, Versace V (2005) The consequences of land use change on nutrient exports: a regional scale assessment in southwest Victoria, Australia. J Environ Mgmt 74:305-316

Phillips B, Ghafouri R (1997) Modeling the effects of land use change. In: Proc. 8th Int. Rainwater Catch Sys. Conf. Tehran Iran Abs. 6.15 p. 61. http://www.eng.warwick.ac.uk/ircsa/abs/ 8th/abs8.pdf

WP Software (1995) XP-AQUALM. http://www.xpsoftware.com/ products/pdfs/Aqmtdes.pdf

Versace V, Ierodiaconou D, Stagnitti F, Hamilton A (2008) Appraisal of random and systematic land cover transitions for regional water balance and revegetation strategies. Agric Ecosys Environ 123(4):328-336

Water Resources Institute (2000) Annual renewable water supply per person by river basin. http://earthtrends.wri.org/maps_spatial/ maps_detail_static.php?map_select $=265 \&$ theme $=4$ 